\title{
Ikwi-tang for the treatment of allergic rhinitis as a traditional medicine
}

\author{
Ji-Hyun Go ${ }^{1}$, Jae-Hun Jung ${ }^{1}$, Yu-Jung Chang ${ }^{2}$, Hyung-Min Kim ${ }^{1}$, Yun-Jo Chung, ${ }^{2}{ }^{*}$ \\ ${ }^{1}$ Department of Pharmacology, College of Korean Medicine, Kyung Hee University, Seoul,130-701, Republic of Korea; ${ }^{2}$ Center for \\ University-Wide Research Facilities, Chonbuk National University, Jeonju, 561-756, Republic of Korea
}

\begin{abstract}
Ikwi-tang (IW) is an oriental medicine that has been used for the treatment of general symptoms due to a stomach yin deficiency. The aim of this study is to investigate precisely the effect of IW on allergic rhinitis (AR). We well show the effects and the mechanism of IW in the ovalbumin-sensitized AR model. IW significantly decreased the number of nasal/ear rubs and the increment of IgE levels in the AR mice. The levels of interferon- $\gamma$ were enhanced while the levels of interleukin (IL)- 4 were reduced in the spleen tissue of the IW-administered AR mice. Expressions of IL-1 $\beta$ and cyclooxygenase- 2 were inhibited by IW-administration in the nasal mucosa tissues. Infiltration of eosinophils and mast cells was decreased in the IW-administered AR mice. Our results indicate that IW may attenuate the development of AR by the inhibition of caspase-1 activity.
\end{abstract}

Keywords Ikwi-tang, allergic rhinitis, IL-1 $\beta$, caspase-1

\section{INTRODUCTION}

Allergic rhinitis (AR) is a common manifestation of allergic diseases, affecting approximately 500 million people worldwide (Bousquet et al., 2008). Although not life threatening, AR can deteriorate the quality of life and can be a major risk. Despite its clinical and socioeconomic impact, advances in its treatment still have a long way to go (Lee et al., 2007). Many of the symptoms of patients with AR, including sneezing, itching, and respiratory obstruction cause a lot of pain. However, the symptoms of AR do not end here. If prolonged, $\mathrm{AR}$, can cause problems in the nasal voice box, and can cause very severe eye and ear symptoms (Hellings and Fokkens, 2006). These symptoms are due to the release of histamine and other active substances by mast cells, which stimulate the dilation of blood vessels, irritate nerve endings and increase the secretion of tears (Whitcup, 2006).

Since the discovery by Coffman and colleagues (1986) of two distinct types of Th in mice, mutual regulation between Th1 cells and Th2 cells has been considered important for homeostatic maintenance of the immune system in the whole body. Dysregulated Th1 and Th2 responses lead to excessive Th1 cell or Th2 cell activation, resulting in the development of autoimmune diseases associated with the accumulation of Th1 cells or in an induction of allergic diseases due to the accumulation of Th2 cells, respectively (Bach, 2002). In response to exposure to allergens, patients with AR present an inflammatory IgE-mediated response characterized by a Th2 immunologic pattern with mast cells and eosinophils activation and the release of inflammatory mediators, IL-1 $\beta$, IL-6, and TNF- $\alpha$ (Howarth et al., 2003; Johansson et al., 2011).. Leukotrienes and prostanoids produced by the 5-lipoxygenase and cyclooxygenase (COX)-2 pathways have potent pro-inflammatory and vascular actions that implicate them in

\footnotetext{
${ }^{*}$ Correspondence: Yun-Jo Chung

E-mail: yjchong@jbnu.ac.kr

Received November 27, 2012; Accepted February 15, 2013;

Published February 28, 2013

doi: http://dx.doi.org/10.5667/tang.2012.0043

C 2013 by Association of Humanitas Medicine

TANG / www.e-tang.org
}

allergic and inflammatory reactions (Montuschi et al., 2007). Eosinophils are innate effector cells that are important in immune responses against helminth parasitic infections and contribute to the pathology associated with allergic inflammatory conditions. Mast cells contribute to the induction and/or maintenance of eosinophilic inflammation by a variety of mechanisms, including IgE-dependent and IgE-independent processes (Pawankar et al., 2007). The recruitment of these mast cells to inflammatory sites occurs in response to chemotactic and activation signals (Bournazou et al., 2007).

Caspase-1 is a member of the cystein-aspartic acid protease (caspase) family (Stutz et al., 2009). Caspase-1 is characterized by its ability to activate the inactive precursors of IL- $1 \beta$ and IL-18 that are involved in inflammation. Caspase- 1 contains an $\mathrm{N}$-terminal caspase recruitment domain (CARD). This CARD promotes the proteolytic activation of the recruited caspase-1 in inflammation (Lamkanfi et al., 2003). Caspase-1 is activated within inflammasome, a large cytosolic protein complex that is induced by a growing number of endogenous, microbial, chemical or environmental stimuli (Yazdi et al., 2010).

Ikwi-tang (IW) is an oriental medicine that has been used for the treatment of general symptoms due to a stomach yin deficiency (胃陰虛). In traditional Korean medicine, a stomach yin deficiency means a pathological change characterized by a deficiency of fluid in the stomach with impaired function attributable to intense stomach fire or exuberant heat in a warm disease. The function of the lungs (肺) could be made worse due to a stomach yin deficiency, because the stomach yin deficiency is able to induce the transportation and transformation disorder (運化失調). Donguibogam, a Korean traditional medical book, says that Liriopis Tuber has improved dyspnea and Rehmanniae Radix is a great thirst quencher and is known as an ani-constipation medicine. Adenophorae Radix comforts the human body and strengthens the stomachs, intestines and lungs and works to repair weak bodies as well as improve a women's beauty. Polygonati odorati Rhizoma comforts all the organs and protects the stomach and spleen; Saccharum Nigrum improves human body Qi and enriches the lungs and stomach. Then a dysfunction of the lungs could induce AR. Taken together, AR can be induced by the stomach 
Table 1. The amount and composition of IW

\begin{tabular}{lll}
\hline Herbal name & Scientific name & Dose (g) \\
\hline Maekmundong & Liriopis Tuber & 18.75 \\
Saengjihwang & Rehmanniae Radix & 18.75 \\
Sasam & Adenophorae Radix & 11.25 \\
Okjuk & Polygonati odorati Rhizoma & 5.625 \\
Bingdang & Sacchrum Glacialis & 3.75 \\
\hline
\end{tabular}

yin deficiency in traditional Korean medical theory.

In this study, we investigated the regulatory activity of IW on an ovalbumin (OVA)-induced AR mice model.

\section{MATERIALS AND METHODS}

\section{Materials}

Ovalbumin (OVA), O-phthaldialdehyde (OPA), avidin peroxidase, 2'-azino-bis (3-ethylbenzithiazoline-6-sulphonic acid) tablets substrate (ABTS), and other reagents were purchased from Sigma (St. Louis, MO, USA). Anti-mouse IgE/IL-1 $\beta /$ IL-4/IFN- $\gamma$ antibody (Ab), biotinylated anti-mouse IgE/IL-1 $\beta / \mathrm{IL}-4 / \mathrm{IFN}-\gamma \mathrm{Ab}$, and recombinant mouse (rm) IgE/IL-1 $\beta /$ IL-4/IFN- $\gamma$ were purchased from Pharmingen (Sandiego, CA, USA). Ab for COX-2, and actin were obtained from Santa Cruz Biotechnology (Santa Cruz, CA, USA). The caspase-1 assay kit was supplied by R\&D Systems Inc. (Minneapolis, MN, USA).

\section{Preparation of IW}

A sample of IW was obtained from an oriental drug store, Noa Pharmacy (Seoul, Republic of Korea), and then authenticated by Kim HM, College of Pharmacy, Kyung Hee University. A voucher specimen was deposited at the Pharmacology of the College of Oriental Medicine (IW: voucher No 304047), Kyung Hee University. IW was extracted by decocting the dried herbs (total $58.125 \mathrm{~g}$ ) (Table 1) with boiling distilled water (1 l ) for approximately $2 \mathrm{~h} 30 \mathrm{~min}$. An IW yield of $9.7 \%$ by freeze-drying was obtained. The decoction was then filtered, lyophilized and kept at $4^{\circ} \mathrm{C}$. Dilutions were then made with distilled water and filtered through a $0.22 \mu \mathrm{m}$ syringe filter. The dose of IW for an adult person can be $0.1 \mathrm{~g} / \mathrm{kg}$. The dose range of $0.01-1 \mathrm{~g} / \mathrm{kg}$ was chosen to see the dose dependency (Moon et al., 2005).

\section{OVA-induced AR animal model}

We maintained 6-week-old female BALB/c (Charles River Technology) mice under pathogen-free conditions. Mouse care and experimental procedures were performed under approval from the Animal Care Committee of Kyung Hee University. We sensitized the mice on days 1,5 , and 14 by an intraperitoneal injection of $100 \mu \mathrm{g}$ OVA emulsified in $20 \mathrm{mg}$ aluminum hydroxide (Sigma) and we challenged the mice with $1.5 \mathrm{mg}$ OVA. IW was administrated orally before the intranasal (i.n.) OVA challenge for 10 days. Nasal symptoms were evaluated by counting the number of nasal rubs that occurred in the 10 minutes after OVA i.n. provocation at 10 days after the challenge.

\section{Histamine assay}

The histamine content of serum was measured by the OPA spectrofluorometric procedure. The fluorescent intensity was measured at $460 \mathrm{~nm}$ (excitation at $355 \mathrm{~nm}$ ) using a spectrofluorometer.

\section{Histological examination}

Tissue samples were immediately fixed with $10 \%$ formaldehyde and embedded in paraffin. Each section of the nasal mucosa sample (4 $\mu \mathrm{m}$ thick) was stained with hematoxylin and eosin (H\&E, for eosinophils), alcian blue and safranine $O$ (A\&S, for mast cells) or DAB and immunohistochemical stain (for IL-1 $\beta$ ) before dewaxing and dehydration. The numbers of eosinophils, mast cells and IL-1 $\beta$ on both sides of the septal mucosa were counted. Sections were coded and randomly analyzed by two blinded observers.

\section{Enzyme-linked immunosorbent assay (ELISA)}

A modified ELISA, was used to measure the cytokine on tissue protein. The ELISA was performed by coating 96-well plates with $6.25 \mathrm{ng} /$ well of capture $\mathrm{Ab}$. Before the subsequent steps in the assay, the coated plates were washed twice with PBS containing $0.05 \%$ tween-20 (PBST). All reagents and coated wells used in this assay were incubated for $2 \mathrm{~h}$ at room temperature. The standard curve was generated from known concentrations of cytokine, as provided by the manufacturer. After exposure to the medium, the assay plates were exposed sequentially to each of the biotin-conjugated secondary antibodies, and avidin peroxidase, and an ABTS substrate solution containing $30 \% \mathrm{H}_{2} \mathrm{O}_{2}$. The plates were read at $405 \mathrm{~nm}$. Appropriate specificity controls were included, and all samples were run in duplicate. Production of IgE/IL-1 $1 / \mathrm{IL}-4 / \mathrm{IFN}-\gamma$ in the spleen and IgE/IL-1 $\beta$ nasal mucosa were divided according to the total protein. The protein was determined using a bicinchoninic acid (BCA, Sigma, St. Louis, USA).

Reverse transcription-polymerase chain reaction (RT-PCR) Total RNA was isolated from cells and nasal mucosa according to the manufacturer's specification using an easy-BLUE ${ }^{\mathrm{TM}}$ RNA extraction kit (iNtRON Biotech, Korea). The concentration of total RNA in the final elutes was determined by spectrophotometry. Total RNA $(2.5 \mu \mathrm{g})$ was heated at $65^{\circ} \mathrm{C}$ for $10 \mathrm{~min}$ and then chilled on ice. Each sample was reverse-transcribed to cDNA for 90 min at $37^{\circ} \mathrm{C}$ using a cDNA synthesis kit (Amersham Pharmacia Biotech, Piscataway, NJ, USA). PCR was performed with the following primers for IL-1 $\beta$ (5' AGG CCA CAG GTA TTT TGT CG 3'; 5' GCC CAT CCT CTG TGA CTC AT 3'), GAPDH (5'TTC ACC ACC ATG GAG AAG GC 3'; 5'GGC ATG GAC TGT GGT CAT GA 3') was used to verify whether equal amounts of RNA were used for reverse transcription and PCR amplification from different experimental conditions. The cycling conditions were as follows: $30 \mathrm{sec}$ at $94^{\circ} \mathrm{C}, 30 \mathrm{sec}$ at $55^{\circ} \mathrm{C}, 1 \mathrm{~min}$ at $72^{\circ} \mathrm{C}$ for the IL- $1 \beta$ ( 39 cycles); and $15 \mathrm{sec}$ at $95^{\circ} \mathrm{C}, 45 \mathrm{sec}$ at $62^{\circ} \mathrm{C}, 30 \mathrm{sec}$ at $72^{\circ} \mathrm{C}$ for the GAPDH $(34$ cycles). Amplified fragment sizes for IL- $1 \beta$ and GAPDH were $545 \mathrm{bp}$ and $446 \mathrm{bp}$, respectively. Products were electrophoresed on a $1.5 \%$ agarose gel and visualized by staining with ethidium bromide

\section{Caspase-1 assay}

Caspase-1 activity was measured according to the manufacturer's specification using a caspase assay kit (R \& D system). Equal amounts of total protein were quantified by a BCA protein quantification kit (Sigma) in each lysate. The catalytic activity of caspase- 1 from the cell lysate was measured by the proteolytic cleavage of WEHD-pNA for $4 \mathrm{~h}$ at $37^{\circ} \mathrm{C}$. The plates were read at $405 \mathrm{~nm}$. A recombinant caspase-1 enzyme was available for use as a positive control.

\section{Western blot analysis}

Cell extracts were prepared by the detergent lysis procedure. Samples were heated at $95^{\circ} \mathrm{C}$ for $5 \mathrm{~min}$, and briefly cooled on ice. Following the centrifugation at $15,000 \times \mathrm{g}$ for $5 \mathrm{~min}, 50 \mu \mathrm{g}$ aliquots were resolved by $10 \%$ SDS-PAGE. Resolved proteins 
A

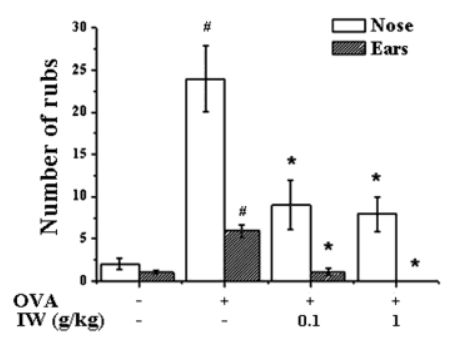

D

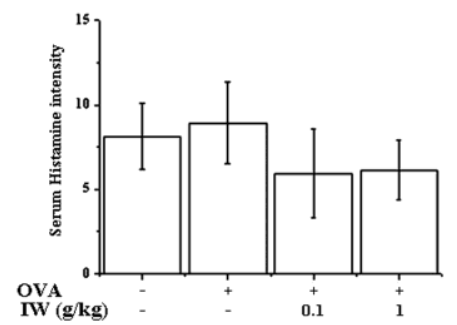

B

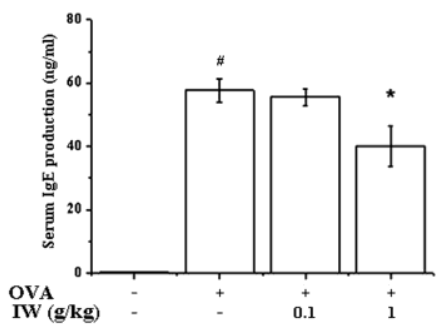

E

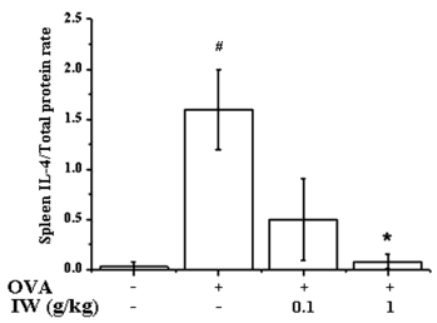

C

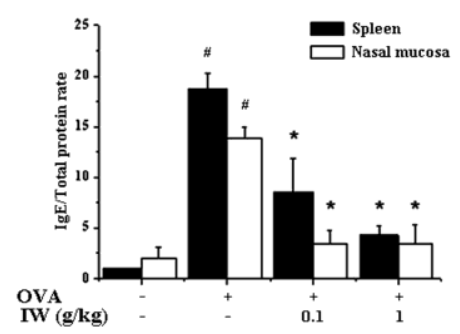

F

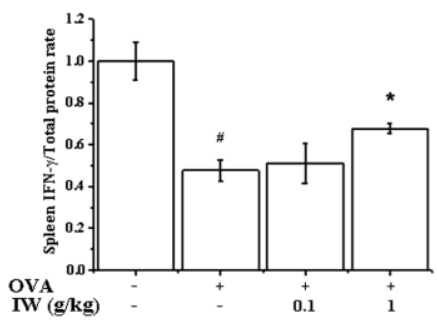

Fig. 1. Effect of IW on clinical symptoms, IgE level, histamine release, and IL-4 and IFN- $\gamma$ levels in the AR model. We sensitized mice on days 1,5 , and 14 by intraperitoneal injections of $100 \mu \mathrm{g}$ OVA emulsified in $20 \mathrm{mg}$ of aluminum hydroxide and we challenged mice with $1.5 \mathrm{mg}$ OVA. Mice received IW before the intranasal OVA challenge for 10 days. (A) The number of the nasal and ear rubs that occurred in the 10 min after the OVA intranasal provocation. (B and $\mathrm{C}$ ) IgE, (E) IL-4, and (F) IFN- $\gamma$ were measured by ELISA method. All parameters measured in the tissue homogenate were presented as a ratio to the total protein level in tissue. (D) Serum was isolated from blood and then assayed about histamine. ${ }^{*}<$ 0.01 ; significantly different from the OVA-unsensitized mice. ${ }^{*} P<0.01$; significantly different from the OVA-sensitized mice. $\mathrm{N}=5$.

were electrotransferred overnight to nitrocellulose membranes in $25 \mathrm{mM}$ Tris, $\mathrm{pH} 8.5,200 \mathrm{mM}$ glycerin, $20 \%$ methanol at 25 V. Blots were blocked for at least $2 \mathrm{~h}$ with $1 \times$ PBS containing $0.05 \%$ tween 20 containing $5 \%$ nonfat dry milk and then incubated with the primary antibodies for $1 \mathrm{~h}$ at room temperature. Blots were developed by peroxidase-conjugated secondary antibodies, and proteins were visualized by enhanced chemiluminescence procedures (Amersham Bioseciences, Piscataway, NJ, USA) according to the manufacturer's instructions.

\section{Statistical analysis}

The experiments shown are a summary of the data from at least three experiments and statistical analyses were performed using SPSS statistical software (SPSS 11.5, USA). Treatment effects were analyzed by one-way ANOVA, offered by Tukey's multiple range tests, and $p<0.05$ was used to indicate significance.

\section{RESULTS}

Effect of IW on clinical symptoms, IgE production, and histamine release in AR animal model

To investigate the inhibitory effect of IW in the AR model, we sensitized mice on days 1,5 , and 14 by intraperitoneal
A

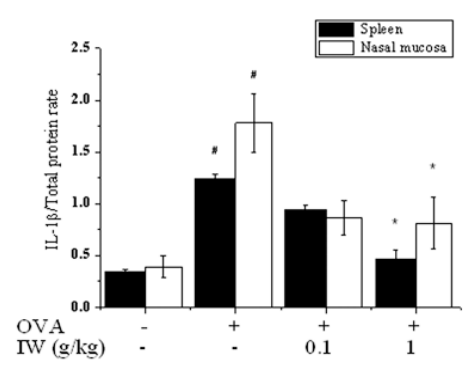

C

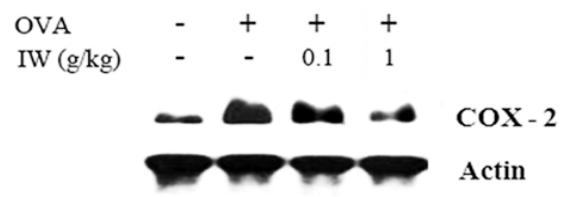

B

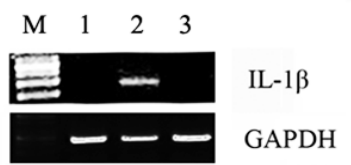

D

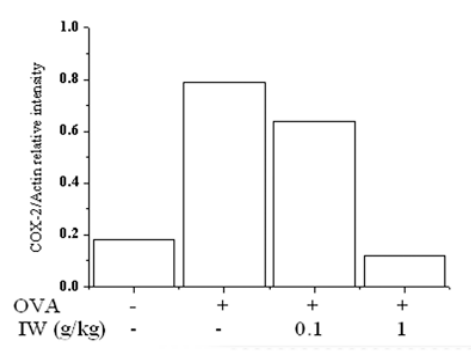

Fig. 2. Effect of IW on inflammatory cytokines and COX-2 expression in AR animal model. We sensitized mice on days 1,5 , and 14 by intraperitoneal injections of $100 \mu \mathrm{g}$ OVA emulsified in $20 \mathrm{mg}$ of aluminum hydroxide and we challenged mice with $1.5 \mathrm{mg}$ OVA. Mice received IW before the intranasal OVA challenge for 10 days. (A) IL- $1 \beta$ was measured by ELISA method in spleen and nasal mucosa tissue. All parameters measured in the tissue homogenate were presented as a ratio to the total protein level in tissue. (B) Messenger RNA was measured using RT-PCR method. (C) COX-2 protein expression was evaluated by using Western blot analysis. (D) The protein levels were quantitated by densitometry. M, marker; 1, OVA-unsensitized; 2, OVA-sensitized; 3, IW $(1 \mathrm{~g} / \mathrm{kg}) \quad+$ OVA-sensitized. ${ }^{\#} P<0.01$; significantly different from the OVA-unsensitized mice. $* P<0.01$; significantly different from the OVA-sensitized mice. $\mathrm{N}=5$. 
injections of $100 \mu \mathrm{g}$ OVA emulsified in $20 \mathrm{mg}$ aluminum hydroxide and challenged mice with $1.5 \mathrm{mg}$ OVA. The number of nasal and ear rubs after the OVA challenge in the OVA-sensitized mice was significantly higher than those in the OVA-unsensitized mice. Increased rub score was inhibited by treatment of IW (Fig. 1A). Levels of OVA-specific IgE in the AR mice were significantly higher than those in the serum, spleen, and nasal mucosa tissues of the OVA-unsensitized mice (Fig. 1B and C). Increased IgE levels in each tissue were reduced by IW. Histamine level in serum was reduced by IW (Fig. 1D). To identify the Th1/Th2 immune reaction in IW-administered mice, we measured IL-4 and IFN- $\gamma$ production. As shown in Fig. 1E, the level of IL-4 in the AR mice was significantly increased compared to that in the normal mice. IL-4 level was significantly decreased in the IW-administered AR mice. However, IFN- $\gamma$ level was significantly increased in the IW-administered AR mice (Fig. $1 \mathrm{~F})$.

Effect of IW on inflammatory cytokines and COX-2 levels in $A R$ animal model

To evaluate the regulatory effects of IW on inflammatory cytokine production, we measured the protein and mRNA levels of IL- $1 \beta$ in the AR model. The protein levels of IL- $1 \beta$ in the spleen and nasal mucosa tissue were increased in the OVA-sensitized mice compared to in the OVA-unsensitized mice (Fig. 2a). However, protein levels of IL-1 $\beta$ were inhibited in the IW administered mice compared to the OVA-sensitized mice $(p<0.05)$. The effect of IW on IL-1 $\beta$ mRNA expression induced by the OVA was examined by using RT-PCR analysis with nasal mucosa tissue. As a result, IW inhibited the OVA-induced IL-1 $\beta$ mRNA expression (Fig. 2b). In addition, the expression of COX-2 was inhibited by the administration of IW in the nasal mucosa tissue (Fig. 2c and d).

Effect of IW on eosinophils and mast cell infiltration and IL-1 $\beta$ expression in the nasal mucosa tissues

The respective numbers of inflammatory cells (eosinophils and mast cells) in the nasal mucosa in the AR mice were significantly higher than those in the control mice. In the IW-administered mice, eosinophils and mast cells infiltration increased by OVA sensitization was decreased (Fig. 3a and b). Immunohistochemical analysis of the nasal mucosa sections in the AR mice revealed that IL- $1 \beta$ is highly expressed, whereas in the IW-administered mice it is decreased (Fig. 3a and b).

\section{Effect of IW on caspase-1 activity in nasal mucosa}

Caspase-1 plays a key role in inflammatory responses by cleaving pro-IL-1 $\beta$ into secreted pro-inflammatory cytokines. To investigate the effect of IW on caspase-1 activation, caspase-1 assay were performed with the nasal mucosa tissues. As shown in Fig. 4a, IW inhibited OVA-induced caspase-1 activation. IW also reduced the IL-1 $\beta$ levels in the serum (Fig. 4b)

\section{DISCUSSION}

In this study, IW reduced the allergic and inflammatory reactions in the AR animal model. AR is characterized by a two-phase allergic reaction. In the early-phase inflammatory response allergen-IgE dependent activation of mast cells and basophils results in the production of pharmacologically active mediators such as histamine, prostaglandins, leukotrienes, and cytokines which produce sneezing, rhinorrhea, and itching (Jeong et al., 2009). Recruitment of inflammatory cells, including eosinophils, basophils, and $\mathrm{T}$ cells, results in the

further release of histamine and leukotrienes, as well as other compounds including proinflammatory cytokines, COX-2, and chemokines; this sustains the allergic response and promotes the late phase response (Fuentes et al., 2009 Fukui et al., 2009).

Inflammasomes are multiprotein cytoplasmic complexes that mediate the activation of inflammatory caspase-1 (Woschnagg et al., 2009). Caspase-1-/- mice have decreased the production of IL- 6 after stimulation with lipopolysaccharide (Kim et al., 2008). For IL-1 $\beta$ an intracellular cysteine protease, caspase-1, is required for processing the inactive precursors into mature, active forms that can then be secreted from the cell. The activation of caspase- 1 is itself tightly controlled and provides yet another unique mechanism to limit inflammation (Kim et al., 2008). Blocking IL-1 $\beta$ in auto-inflammatory diseases often results in a decrease in the activity of the inflammasome. Specific adaptor molecules of the receptor interacting protein-2 (RIP2, CARD containing kinase) regulate

A

$\mathrm{H} \& \mathrm{E}$

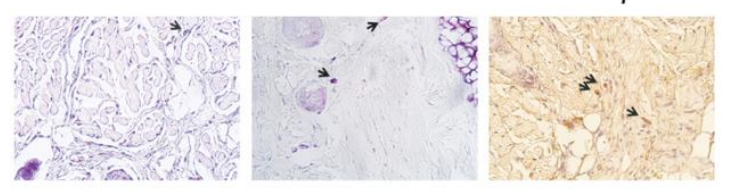

OVA - unsensitized
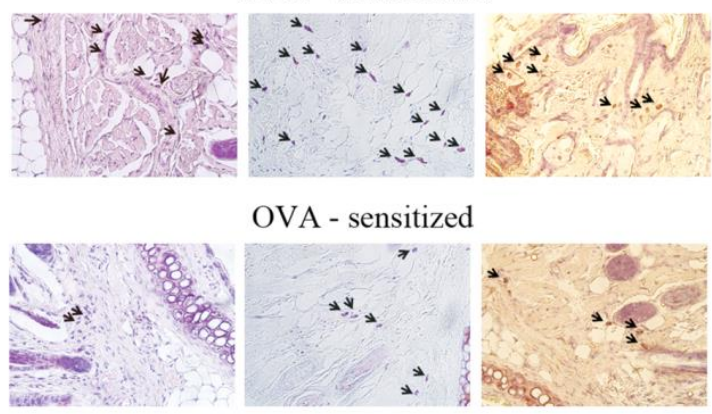

IW + OVA - sensitized

B

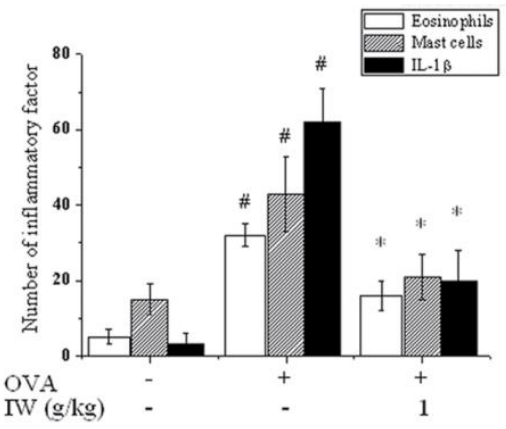

Fig. 3. Effect of IW on infiltration of eosinophils and mast cells and levels of IL-1ß in nasal mucosa. (A) Nasal mucosa stained with H\&E (for eosinophils), alcian blue and safranine $\mathrm{O}$ (for mast cells), and immunohistochemical DAB stain (for IL-1 $\beta$ ). Eosinophils, mast cells, and IL-1 $\beta$ were indicated by arrows. (B) Eosinophils, mast cells, and IL-1 $\beta$ were counted by two individuals. After five randomly selected tissue sections per mouse were counted. The absolute number of cells was counted as the mean \pm standard error of the mean (S.E.M.). ${ }^{\#} P<$ 0.01 ; significantly different from the OVA-unsensitized mice. $* P<$ 0.01 ; significantly different from the OVA-sensitized mice. (Original magnification $\times 400$ ).

2013 / Volume 3 / Issue 1 / e8 
A

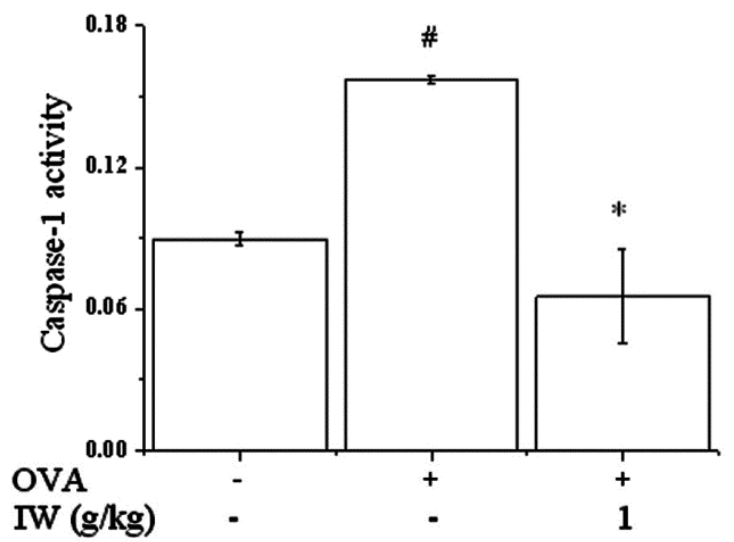

B

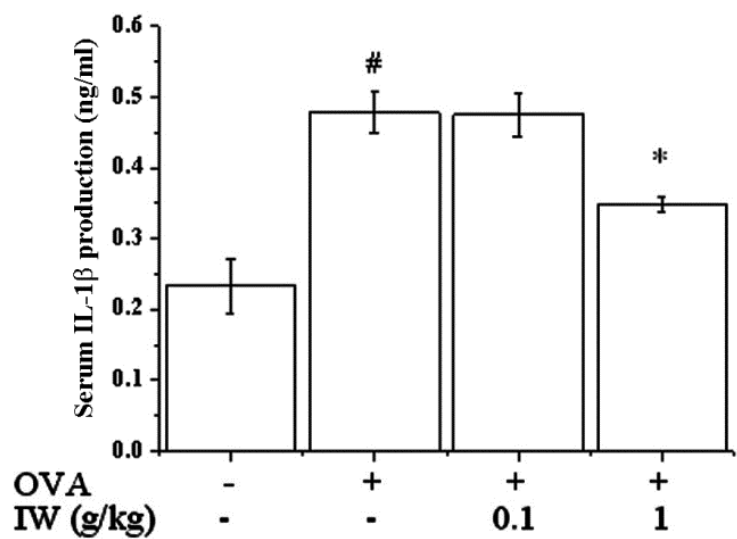

Fig. 4. Effect of IW on caspase-1 activation and IL-1 $\beta$ level in the AR mice. We sensitized mice on days 1,5 , and 14 by intraperitoneal injections of $100 \mu \mathrm{g}$ OVA emulsified in $20 \mathrm{mg}$ of aluminum hydroxide and we challenged mice with $1.5 \mathrm{mg}$ OVA. Mice received IW before the intranasal OVA challenge for 10 days. (A) Protein was assayed about caspse- 1 in nasal mucosa tissue. (B) IL-1 $\beta$ was measured by ELISA method in serum. ${ }^{\#} P<0.01$; significantly different from the OVA-unsensitized mice. ${ }^{*} P<0.01$; significantly different from the OVA-sensitized mice. $\mathrm{N}=5$.

the activation of caspase-1 through CARD-CARD interaction (Martinon, 2005; Kuida et al., 1995). RIP2 then recruits the IkB kinase (IKK) complex through direct interaction of its intermediate domain with IKK-b, leading to the activation of NF-kB (Chin et al., 2002; Ogura et al., 2001; Yoo et al., 2002).

However, RIP2/RICK/CARDIAK is a member of the RIP family. RIP2 promotes NF-kB activation as well as the activation of the MAPKs JNK, ERK1/2, and p38 MAPK and the transcription of inflammatory-related genes such as those encoding IL-1 $\beta$, IL-6, TNF- $\alpha$, and COX-2. RIP2, moreover, has been shown to interact with the CARD of caspase-1 and to induce IL-1 $\beta$ maturation. Other studies showed that the RIP2 knockout reduced the secretion of the pro-inflammatory cytokines such as TNF- $\alpha$ and IL-6 (Ogura et al., 2001; Yoo et al., 2002). Therefore, we postulated that IW mediates its effects at least partly through the suppression of RIP2/caspase-1 activation.

IW is an oriental medicine that has been used for the treatment of the stomach cover and moisture, gas emissions, cramps, constipation, digestive system and spontaneous chest.
As is already described in the materials and methods section, IW consists of 5 different herbs. Some studies have suggested that beta-sitosterol isolated from Liriopis Tuber, has an inhibition of mast cell activation (Onogawa et al., 2009) and catalpol isolated from Rehmanniae Radix, shows anti-inflammatory activity in vitro (Kim et al., 2009). Use of Adenophorae Radix, resulted in anti-inflammatory activity in an OVA-induced asthma murine model (Roh et al., 2008).

In this study, we confirmed that IW suppressed OVA-induced caspase- 1 activation in the AR model for the first time. This result suggested that the inhibitory effect of IW on IL-1 $\beta$ production might be derived through the regulation of RIP2 and caspase-1 activation. However, further studies will be needed to clarify the role of IW on the RIP2/caspase-1/MAPKs/NF-kB pathway in the AR model.

\section{ACKNOWLEDGMENTS}

This research was supported by Basic Science Research Program through the National Research Foundation of Korea (NRF) funded by the Ministry of Education, Science and Technology (2012R1A1A2A10044645).

\section{CONFLICT OF INTEREST}

The authors have no conflicting financial interests.

\section{REFERENCES}

Bach JF. The effect of infections on susceptibility to autoimmune and allergic diseases. $N$ Engl $J$ Med. 2002;347:911-920.

Bournazou I, Mackenzie KJ, Duffin R, Rossi AG, Gregory CD. Inhibition of eosinophil migration by lactoferrin. Immunol Cell Biol. 2007;88:220-223.

Bousquet J, Khaltaev N, Cruz AA, Denburg J, Fokkens WJ, Togias A, Zuberbier T, Baena-Cagnani CE, Canonica GW, van Weel C, et al. World Health Organization; GA (2) LEN; Allergen. Allergic Rhinitis and its Impact on Asthma (ARIA) 2008 update (in collaboration with the World Health Organization, GA (2) LEN and Allergen). Allergy. 2008;86:8-160.

Chin AI, Dempsey PW, Bruhn K, Jeff FM, Yang X, Genhong C. Involvement of receptor-interacting protein 2 in innate and adaptive immune responses. Nature. 2002;416:190-194.

Fuentes-Beltrán A, Montes-Vizuet R, Valencia-Maqueda E, Negrete-García MC, García-Cruz Mde L, Teran LM. Chemokine CC-ligand 5 production and eosinophil activation into the upper airways of aspirin-sensitive patients. Clin Exp Allergy. 2009;39:491-499.

Fukui N, Honda K, Ito E, Ishikawa K. Peroxisome proliferator-activated receptor gamma negatively regulates allergic rhinitis in mice. Allergol Int. 2009;58:247-253.

Hellings PW, Fokkens WJ. Allergic rhinitis and its impact on otorhinolaryngology. Allergy. 2006;61:656-664.

Howarth PH, Middleton E, Reed C. Allergic and nonallegic rhinitis Vol 2 Allergy principles and practice. $6^{\text {th }}$ ed. 2013 / Volume 3 / Issue 1 / e8 
(Philadelphia, USA: Mosby), 2003.

Jeong HJ, Moon PD, Kim SJ, Seo JU, Kang TH, Kim JJ, Kang IC, Um JY, Kim HM, Hong SH. Activation of hypoxiainducible factor-1 regulates human histidine decarboxylase expression. Cell Mol Life Sci. 2009;66:1309-1319.

Johansson SG, Hiurihane JO, Bruijnzeel-Koomen C, Dreborg S, Haahtela T, Kowalski ML. A revised nomenclature for allergy: an EAACI position statement from the EAACI nomenclature task force. Allergy. 2011;56:813-824.

Kim BH, Park KS, Chang IM. Elucidation of anti-inflammatory protencies of Eucommia ulmoides bark and Plantago asiatica seeds. J Med Food. 2009;12:764-769.

Kim DI, Yang HJ, Park YM, Rha YH, Choung JT, Pyun BY. Clinical manifestations patterns of allergic disease in Korean children under the age of 6: multi-center study. Korean J Pediatr. 2008;51:640-645.

Kuida K, Lippke JA, Ku G, Harding MW, Livingston DJ, Su MS, Flavell RA. Altered cytokine export and apoptosis in mice deficient in interleukin-1B converting enzyme. Science. 1995;267:2000-2003.

Lamkanfi M, Declercq W, Depuydt B. In Caspases-Their role in Cell death and cell survival. Los M and Walczak H ed. (New York, USA: Landes Bioscience and Kluwer Academic), 2003.

Lee SS, Won TB, Kim JW, Rhee CS, Lee CH, Hong SC, Min YG. Effects of Dexamethasone on the Expression of Transforming Growth Factor-b in the Mouse Model of Allergic Rhinitis. Laryngoscope. 2007;117:1323-1328.

Martinon F, Tschopp J. NLRs join TLRs as innate sensors of pathogens. Trends Immunol. 2005;26:447-454.

Montuschi P, Sala A, Dahlen SE, Folco G. Pharmacological modulation of the leukotriene pathway in allergic airway disease. Drug Discov Today. 2007;12:404-412.

Moon PD, NA HJ, Jeong HJ, Hong SH. Inhibitory effect of gamibojungikgitang extract on mast cell-mediated allergic reaction in murine model. J Pharm Pharm Sci. 2005;8:94-101.
Mosmann TR, Cherwinski H, Bond MW, Giedlin MA, Coffman RL. Two types of murine helper T cell clone. I. Definition according to profiles of lymphokine activities and secreted proteins. J Immunol. 1986;136:2348-2357.

Ogura Y, Inohara N, Benito A, Chen FF, Yamaoka S, Nunez G. Nod2, a Nod1/Apaf-1 family member that is restricted to monocytes and activates NF-kappaB. J Biol Chem. 2001;276:4812-4818.

Onogawa M, Sun G, Takuma D, Hamada A, Yokota J, Yoshioka S, Kusunose M, Miyamura M, Kyotani S, Nishioka Y. Animal studies supporting the inhibition of mast cell activation by Eriobotrya japonica seed extract. J Pharm Pharmacol. 2009;61:237-241.

Pawankar R, Lee KH, Nonaka M, Takizawa R. Role of mast cells and basophils in chronic rhinosinusitis. Clin Allergy Immunol. 2007;20:93-101.

Roh SS, Kim SH, Lee YC, Seo YB. Effects of radix adenophorae and cyclosporine A on an OVA-induced murine model of asthma by suppressing to T cells activity, eosinophilia, and bronchial hyperresponsiveness. Mediators inflamm. 2008;2008:781425.

Stutz A, Golenbock DT, Latz E. Inflammasomes: too big to miss. J Clin Invest. 2009;119:3502-3511.

Whitcup SM. Recent advances in ocular therapeutics. Int Ophthalmol Clin. 2006;46:1-6.

Woschnagg C, Rubin J, Venge P. Eosinophil cationic protein (ECP) is processed during secretion. J Immunol. 2009;183:3949-3954.

Yazdi AS, Guarda G, 'Ombrain MC, Drexler SK. Inflammatory caspases in innate immunity and inflammation. J Innate Immun. 2010;2:228-237.

Yoo NJ, Park WS, Kim SY, Reed JC, Son SG, Lee JY, Lee SH. Nod1, a CARD protein, enhances pro-interleukin-1beta processing through the interaction with pro-caspase-1. Biochem Biophys Res Commun. 2002;299:652-658. 